\title{
Wintertime photosynthesis and spring recovery of Ilex aquifolium L.
}

\author{
Magnus Wachendorf ${ }^{(1)}$, \\ Mona Schloz ${ }^{(1)}$, \\ Manfred Küppers ${ }^{(1)}$, \\ Aylin Güney ${ }^{(1)}$ \\ Maik Veste ${ }^{(1-2)}$
}

\begin{abstract}
Former studies using the chlorophyll fluorescence technique on evergreen Ilex aquifolium L. showed that its photosynthetic potential for electron transport in winter recovers quickly when exposed to more favorable conditions. Since little is known, however, about its photosynthetic carbon gain in winter, we investigated its leaf gas exchange over an entire winter and spring period. Measurements were made rotationally in the field and in the laboratory to also investigate if $I$. aquifolium profits from warmer phases during winter in terms of net carbon gain. From the end of autumn until the end of spring, three different climate-driven phases of photosynthetic responses could be distinguished: first, an acclimation phase which lasted until February and was characterized by a gradually decreasing light-saturated gross photosynthesis $\left(\mathrm{A}_{\max (\text { gross) }}\right)$, decreasing apparent quantum yield of $\mathrm{CO}_{2}$-assimilation $\left(\phi_{i}\right)$ and a decreasing ability of these parameters to recover overnight inside the laboratory. At the same time, maximal quantum yield of PSII $\left(F_{v} / F_{m}\right)$ could fully regenerate. In this phase, single warmer days had a positive effect on carbon assimilation. Second, a phase of relatively constant but low photosynthesis which was virtually unaffected by temperature, lasting for almost two months occurred. Here, $A_{\max (\text { gross) }}$ and $\phi_{i}$ had lost their ability to recover from winter conditions in the field, while $F_{v} / F_{m}$ was much less affected. I. aquifolium was still able to conduct positive light-saturated net photosynthesis at a leaf temperature of -0.5 ${ }^{\circ} \mathrm{C}$, but during this time it could not profit from milder temperatures in terms of carbon gain. Third, a phase of increasing photosynthesis (spring recovery) occurred, starting in March when the 5-day average temperature was above 5 ${ }^{\circ} \mathrm{C}$ and radiation in the field increased, and where all parameters slowly recovered from winter depressions. Our findings show that $I$. aquifolium is photosynthetically active over the whole winter, even at temperatures around $0{ }^{\circ} \mathrm{C}$. In terms of carbon gain, however, I. aquifolium does not profit from warmer phases during winter, despite the fast recovery seen in chlorophyll fluorescence measurements.
\end{abstract}

Keywords: Chlorophyll Fluorescence, Frost, Leaf Gas Exchange, Photosynthetic Induction, Quantum Yield, Respiration trees in Central Europe and it is the northernmost widespread, usually growing in the understory of forests. Its distributional range is closely climate-related and relatively similar to that of European beech (Fagus sylvatica): towards south-west Euited by decreasing water availability; there, I. aquifolium primarily grows at higher altitudes and sites with higher humidity (Pott 1990, Arrieta \& Suárez 2006). The northern rope (e.g., Spain), it becomes gradually lim-

(1) Universität Hohenheim, Institut für Botanik 210a, Garbenstraße 30, D-70599 Stuttgart (Germany); (2) CEBra - Centrum für Energietechnologie Brandenburg e.v., Friedlieb-RungeStraße 3, D-03046 Cottbus (Germany)

@ Magnus Wachendorf (magnus.wachendorf@uni-hohenheim.de)

Received: Oct 23, 2018 - Accepted: May 21, 2019

Citation: Wachendorf M, Schloz M, Küppers M, Güney A, Veste M (2019). Wintertime photosynthesis and spring recovery of Ilex aquifolium L. iForest 12: 389-396. - doi: 10.3832/ifor2983-012 [online 2019-07-31]

Communicated by: Claudia Cocozza and eastern distribution is closely related to the $0{ }^{\circ} \mathrm{C}$ isoline in January (Iversen 1944). As a result of increasing winter temperatures within the last decades, this isoline has shifted more to the north and east and now runs from the southwest coast of Norway via the south of Sweden to northeast Germany. With the isoline shift, I. aquifolium increased its distribution range across northern and eastern Europe (Banuelos et al. 2004, Walther et al. 2005, Berger 2008). It is likely that global warming will continue to shift climate zones in the future and, as a consequence, the distribution ranges of species and compositions of forest ecosystems will change (Sykes et al. 1996, Bussotti et al. 2015).

The central populations of I. aquifolium, on the other hand, might profit from generally milder temperatures or single warmer days in winter and could potentially become more established in the understory of northern and eastern European forests: their ability to conduct photosynthesis during winter and early spring leads to an ecological advantage over deciduous trees (Veste \& Kriebitzsch 2010). Increasing win- 
ter temperatures could additionally increase photosynthetic rates and thus further increase the competitiveness of evergreen species. The ability to immediately take advantage of an extended growing season may also prove advantageous for $I$. aquifolium in the event of climate change.

In winter, however, leaves of evergreen plants may become photoinhibited, as induced by low temperatures in combination with high light intensities, thereby reducing photosynthetic efficiency, a phenomenon known in conifers of the temperate and boreal zones (Gillies \& Vidaver 1990, Slot et al. 2005) and in many Mediterranean evergreens (García-Plazaola et al. 2003). Photoinhibition is accompanied by a decrease in maximal potential PSII efficiency $\left(F_{v} / F_{m}\right)$, as has been shown for $l$. aquifolium (originating from different habitats and climates) in experiments in winter (Groom et al. 1991, Valladares et al. 2005, Veste \& Kriebitzsch 2010). In the experiments of Groom et al. (1991) and Veste \& Kriebitzsch (2010), however, $F_{v} / F_{m}$ could fully recover within hours after plants were exposed to more favorable conditions. These results, obtained by the chlorophyll fluorescence technique, show a high plasticity of the electron transport related part of photosynthesis.

In this study we additionally investigate the potential of I. aquifolium to profit from warmer phases during winter in terms of carbon gain. Objectives were: (i) to investigate photosynthetic performance $\left(\mathrm{CO}_{2}\right.$ gas exchange) in $\mathrm{I}$. aquifolium during winter and subsequent spring; (ii) to study if a temperature increase in winter has a positive effect on carbon gain, since an increase in $F_{v} / F_{m}$ does not necessarily indicate an increase in the rate of photosynthesis.

\section{Material and methods}

\section{Plant material and experimental sites}

Five saplings of I. aquifolium L. were used in the experiment. The plants were obtained from a nursery and, to the best of our knowledge, wild-types (no varieties) from northwestern Germany. They were about $70 \mathrm{~cm}$ in height, potted in 5 I pots in a fertilized white peat substrate with a $\mathrm{pH}$ of 4.5. Three of the plants which were used for field measurements were dug into the ground (but remained in their pots for easy transport) at a nearby site in the Botanical Gardens of the University of Hohenheim, Baden-Württemberg, Germany $\left(48^{\circ} 42^{\prime}\right.$ $35.79^{\prime \prime} \mathrm{N}, 09^{\circ} 12^{\prime}$ 39.6" E; about $373 \mathrm{~m}$ a.s.l.). Mean annual temperature is $9.7^{\circ} \mathrm{C}$ with a mean annual precipitation of $736 \mathrm{~mm}$ ("Klima- und Wetterstation Hohenheim" from 1981-2010). During the experiment, additional microclimatic data were collected using a WatchDog Weather Station (2000 Series ${ }^{\circledast}$, Spectrum Technologies, Plainfield, IL, USA) directly next to the plant site. Air temperature $\left({ }^{\circ} \mathrm{C}\right)$ and global radiation $\left(\mathrm{Wm}^{-2}\right)$ were measured in the field at about $1.5 \mathrm{~m}$ height in $10 \mathrm{~min}$ intervals. Two plants used as references were kept inside the laboratory at room temperature $\left(\approx 21{ }^{\circ} \mathrm{C}\right.$ and $\approx 40 \%$ relative humidity, $\mathrm{RH}$ ) and illuminated 9 hours a day with photosynthetically active radiation (PAR) of up to $400 \mu \mathrm{mol} \mathrm{m} \mathrm{m}^{-2} \mathrm{~s}^{-1}$ under an artificial light source (NAV-T $\mathrm{T}^{\circledast}, 400 \mathrm{~W}$, OSRAM, Germany); plants were well-watered.

\section{Measurement approach}

Measurements were carried out from November 2013 to July 2014, always following the same procedure (principle shown in Fig. 1): the evening before plants were measured in the field, one leaf of each plant was wrapped in aluminum foil to keep it in darkness so that photosynthesis could not be induced at sunrise. In the subsequent morning hours, photosynthetic induction gain was measured in these darkened leaves (circles on Monday in Fig. 1), followed by a light response curve (see below). These measurements were identically performed on the same leaves and in the same order during the whole experimental period. During measurements of leaf gas exchange, chlorophyll fluorescence (triangles in Fig. 1) was measured in three further leaves of each plant, resulting in nine
Fig. 1 - Illustration of the temporal schedule of the experiment. Further explanations in the text.

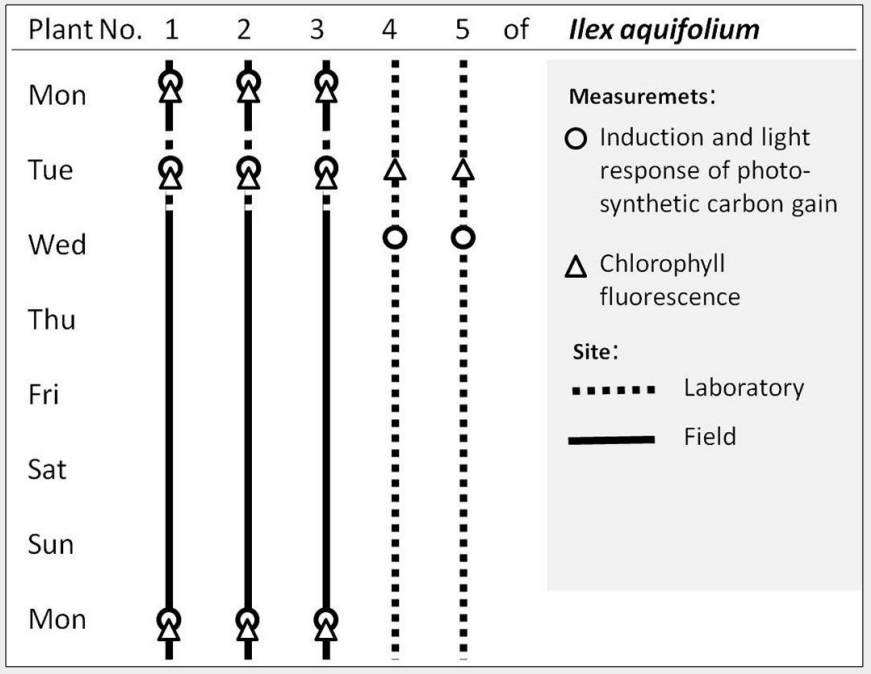

leaves in total (see below). In the evening, plants were transported from the field into the laboratory to induce temperature acclimation overnight. Thereafter, the same measurement procedure was repeated the following (Tuesday) morning (now in the laboratory) and chlorophyll fluorescence was measured in three leaves of every reference plant (six leaves in total). Afterwards, plants were once again exposed for at least five days to ambient conditions in the field and until the start of the next series of measurements. On the third day (Wednesday), photosynthetic induction gain and light response curves in one or both reference plants were measured in the laboratory, always using the same leaves over the whole experimental period.

\section{Photosynthetic induction}

Low photosynthetic induction strongly limits carbon gain (Way \& Pearcy 2012). The faster dark-acclimatized leaves become induced by light, the faster these limits to carbon gain decline. In order to evaluate if low temperatures critically affect this velocity of induction gain in light, the continuous increase of photosynthetic carbon gain following a rectangular step in light was monitored with the portable gas exchange fluorescence system GFS 3000 (Heinz Walz $\mathrm{GmbH}$, Effeltrich, Germany). Once inside the darkened porometer chamber, leaves were allowed to adjust to the measurement conditions for at least $10 \mathrm{~min}$. For leaves measured in the field, leaf temperature $\left(\mathrm{T}_{\text {leaf }}\right)$ was kept constant at about $1{ }^{\circ} \mathrm{C}$ above ambient temperature at the beginning of the experiment to avoid changes in $\mathrm{T}_{\text {leaf }}$ during the measurements. In the laboratory, $\mathrm{T}_{\text {leaf }}$ was always kept constant at 21 ${ }^{\circ} \mathrm{C}$ and about $65 \% \mathrm{RH}$. In both cases, outdoor and indoor, airflow through the cuvette was maintained at $750 \mu \mathrm{mol} \mathrm{s}^{-1}$ with a $\mathrm{CO}_{2}$ concentration of $390 \mu \mathrm{mol} \mathrm{mol}^{-1}$. Once $\mathrm{CO}_{2}$ exchange reached steady state, respiration in darkness $\left(R_{D}\right)$ was recorded. Thereafter, leaves were illuminated by a single rectangular step of PAR of $500 \mu \mathrm{mol}$ $\mathrm{m}^{-2} \mathrm{~s}^{-1}$ until light-saturated net photosynthesis $\left(A_{\max }\right)$ was reached (full induction).

Photosynthetic induction $A_{\text {ind(t) }}$ was then calculated according to Chazdon \& Pearcy (1986) as (eqn. 1):

$$
A_{\text {ind }(t)}=\frac{A_{(t)}-R_{D}}{A_{\max }-R_{D}} \cdot 100
$$

where $A_{(t)}$ is net photosynthesis at time $t$. From this, times to reach $50 \%$ of full induction $\left(t_{50 \% A}\right)$ were evaluated.

\section{Light response of net photosynthesis}

Subsequent to the induction measurements, photosynthetic light response curves were measured in these fully induced leaves. When ambient temperatures during induction measurements rose by a few degrees, leaf temperature was re-adjusted (to $1{ }^{\circ} \mathrm{C}$ above ambient). After leaves were acclimatized, measurements started at PAR of $500 \mu \mathrm{mol} \mathrm{m} \mathrm{m}^{-2} \mathrm{~s}^{-1}$, followed by a 
stepwise decrease. Data were recorded at PAR of 500, 400, 300, 100, 50, 20, 10, 5 and $0 \mu \mathrm{mol} \mathrm{m} \mathrm{m}^{-2} \mathrm{~s}^{-1}$, allowing for a new steadystate of $\mathrm{CO}_{2}$ exchange (after $2.5 \mathrm{~min}$ ) between light steps. From light response curves, several parameters were evaluated: light compensation point $\left(\mathrm{I}_{\text {comp }}\right)$ as the light at which net photosynthesis is zero; light saturation of photosynthesis $\left(\mathrm{I}_{\text {sat }}\right)$ as the light at which $90 \%$ of $A_{\max }$ is reached; apparent quantum yield of $\mathrm{CO}_{2}$ assimilation $\left(\phi_{i}\right)$ estimated as the slope of the initial linear part of the light response curve (usually between PAR of 10 and 50 $\mu \mathrm{mol} \mathrm{m} \mathrm{m}^{-1}$ but above the so-called "Kok effect"); respiration in light $\left(R_{1}\right)$ estimated by extending this linear part to the $y$-axis and $A_{\max (\text { gross })}=A_{\max }+\left|R_{1}\right|$. Since $T_{\text {leaf }}$ could differ by more than $30{ }^{\circ} \mathrm{C}$ between winter and spring, $A_{\max (g r o s s)}$ was used to better illustrate the $\mathrm{CO}_{2}$ uptake without the temperature-dependent effects of respiration.

\section{Chlorophyll fluorescence}

Maximum quantum yield of PSII $\left(F_{v} / F_{m}\right)$ in darkened leaves was determined using a MINI-PAM $^{\circledast}$ (Heinz Walz $\mathrm{GmbH}$, Effeltrich, Germany - eqn. 2):

$$
F_{v} / F_{m}=\left(F_{m}-F_{0}\right) / F_{m}
$$

where $F_{v}$ is the maximal variable fluorescence and $F_{m}$ and $F_{0}$ the maximal and minimal fluorescence yields of the darkened samples respectively. Dark acclimation was initiated for at least $15 \mathrm{~min}$ prior to the measurements using leaf clips (DLC-8).

\section{Statistics}

To evaluate statistical differences between groups of leaves measured in the field and the same leaves measured in the laboratory, paired $t$-tests were performed with Sigmaplot ${ }^{\circledast}$ ver. 12.0 (Systat Software, San Jose, CA, USA). Because of leaf-specific differences, data have been normalized prior to statistical tests.

\section{Results}

\section{Weather conditions during the experimental period}

Daily radiation, air temperature and duration of frosts during the period of measurements are shown in Fig. 2a-c. Overall, temperatures were exceptionally mild during the winter of 2013/2014 (fourth warmest winter in Germany since 1881 - DWD 2014), so that no severe frost was observed and frosty periods never lasted for a complete day. Air temperatures ranged from $-6.5{ }^{\circ} \mathrm{C}$ in December 2013 to $37.4{ }^{\circ} \mathrm{C}$ in June 2014. Freezing usually occurred overnight or in the early morning. There were only a few days where temperatures of $0^{\circ} \mathrm{C}$ or slightly below lasted during daytime. Fig. $2 \mathrm{~d}$ shows mean temperatures of the five days (Wednesday to Sunday in Fig. 1) prior to the measurements conducted in the field, as well as the sum of radiation over these five days. The coldest 5-day periods (means $<1^{\circ} \mathrm{C}$ ) plants were exposed to in the field occurred during mid-December (mean of $-0.5^{\circ} \mathrm{C}$ ) and two periods in series between the end of January and beginning of February (both means $\approx 0.9{ }^{\circ} \mathrm{C}-$ Fig. $2 \mathrm{~d}$ ).

\section{Respiration and photosynthesis in winter}

Respiration during winter was relatively low, since $R_{D}$ and $R_{1}$ clearly depended on temperature in leaves of all plants and over the whole period (Fig. 3). From $0{ }^{\circ} \mathrm{C}$ to about $10{ }^{\circ} \mathrm{C}, R_{D}$ and $R_{I}$ showed the lowest respiration (i.e., least negative values), which did not change significantly within

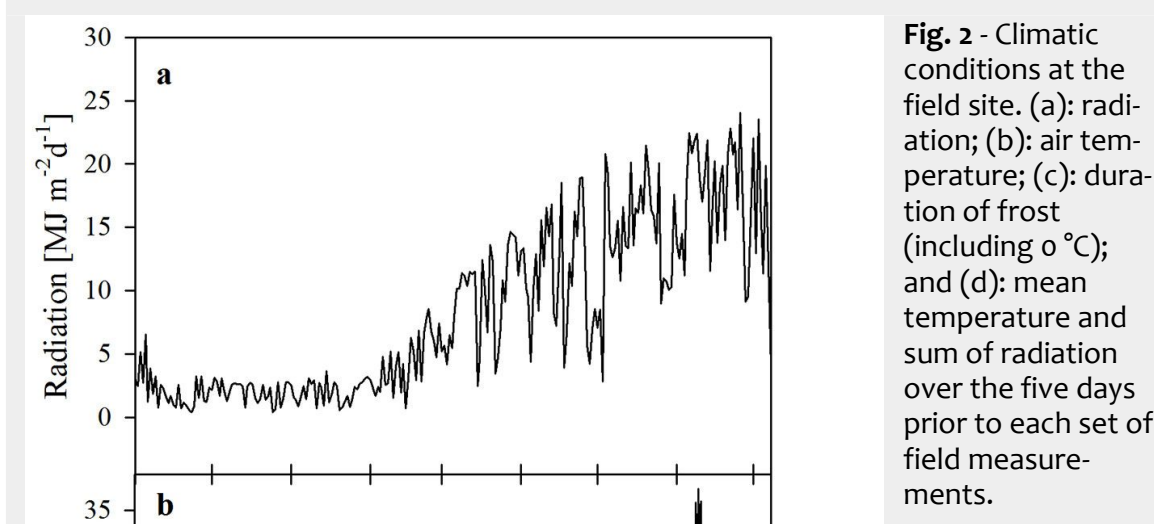

this temperature range (mean values of $\left|R_{D}\right|$ at $0.2-0.3 \mu \mathrm{mol} \mathrm{m}{ }^{-2} \mathrm{~s}^{-1}$, and $\left|R_{1}\right|$ as low as $0.05 \mu \mathrm{mol} \mathrm{m} \mathrm{m}^{-1} \mathrm{~s}^{-1}$ ). Between $10{ }^{\circ} \mathrm{C}$ and about $20{ }^{\circ} \mathrm{C}$ there was a clear increase in respiration and, with the beginning of spring, a large increase from 20 to $35^{\circ} \mathrm{C}$.

Slower activities at low temperatures could also be observed for the velocity of photosynthetic induction, which depends on the activity of enzymes in the Calvin-cycle and on stomatal opening (see review by Kaiser et al. 2015). Independent of photosynthetic rates, photosynthesis was induced more quickly with increasing $T_{\text {leaf }}$ (measured as time to reach $50 \%$ of full in- 


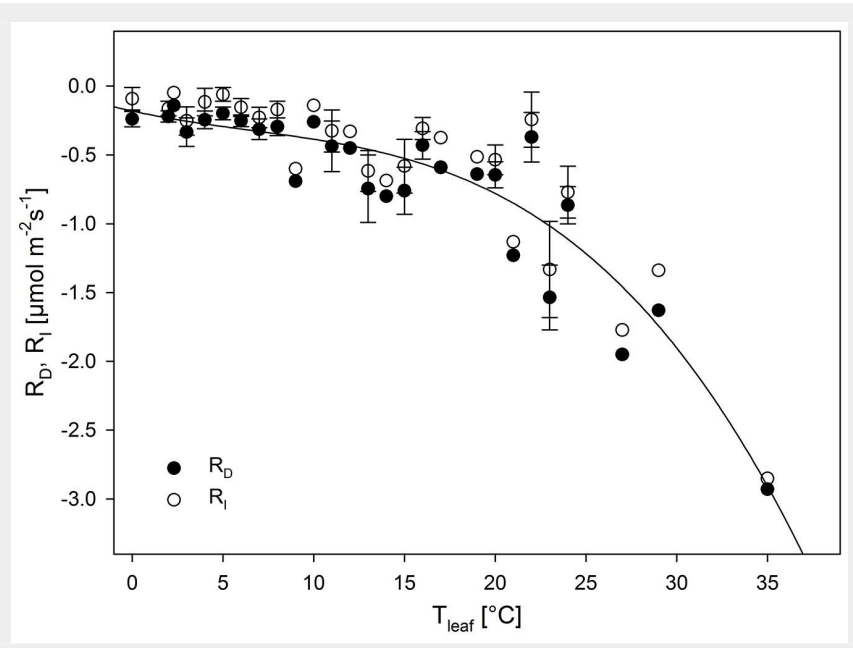

Fig. 3 - Respiration in darkness $\left(R_{D}\right)$ and in light $\left(R_{I}\right)$ at different leaf temperatures $\left(T_{\text {leaf }}\right)$ as obtained over the whole experimental period (November to July). Values are means \pm SE $(n=1-8)$. $R_{D}$ is also described as the regression: $R_{D}=-0.1806-0.0291 \cdot T_{\text {leaf }}$ $+0.0018 \cdot T^{2}$ leaf $-0.0001 \cdot T^{3}$ leaf $; r^{2}=0.73$.

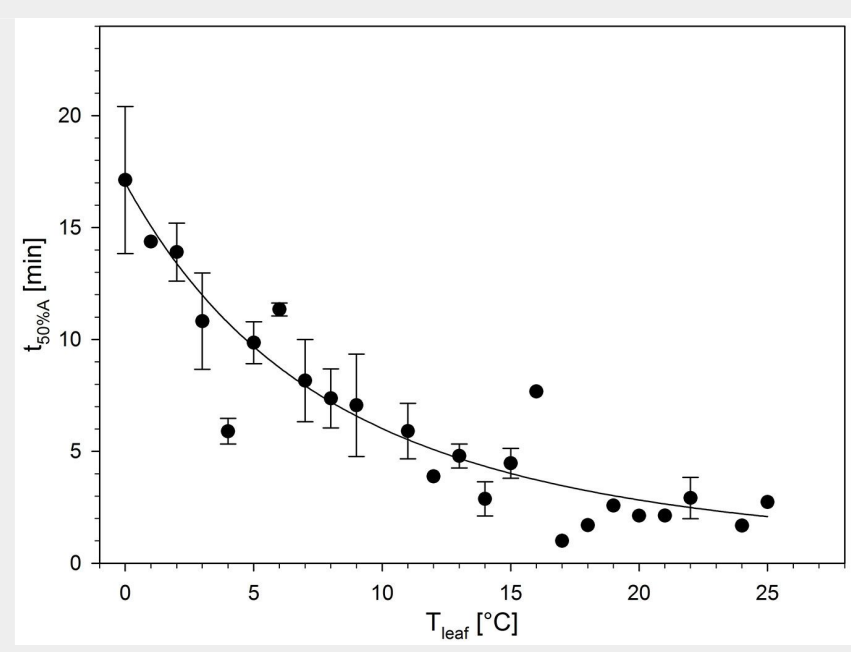

Fig. 4 - Time to reach $50 \%$ of full photosynthetic carbon gain induction $\left(t_{50 \% A}\right)$ in relation to leaf temperature $\left(T_{\text {leaf }}\right)$. Values are means \pm SE $(n=1-12) . t_{50 \% \mathrm{~A}}$ is also described as the regression: $t_{50 \% A}=0.0233 \cdot \exp \left(352.6577 /\left(T_{\text {leaf }}+53.5026\right)\right) ; r^{2}=0.61$.

duction, $t_{50 \% A}$ from more than 17 min at $0{ }^{\circ} \mathrm{C}$ to less than $3 \mathrm{~min}$ at $\mathrm{T}_{\text {leaf }}$ above $15^{\circ} \mathrm{C}$ (Fig. 4). These temperature-affected induction times are well within the range of other broad-leaved (but deciduous) trees, e.g., Fagus sylvatica and Betula pubescens, observed when stomata did not limit the induction process (Wachendorf \& Küppers 2017). We conclude that in I. aquifolium, even temperatures as low as $0{ }^{\circ} \mathrm{C}$ do not critically reduce the velocity of photosynthetic induction in light.

There were no such clear responses to temperature in other photosynthetic parameters ( $A_{\max }, I_{\text {comp }}, I_{\text {sat }}-$ data not shown). $A_{\max (\text { gross) }}$ as measured in the field changed with time and from this, three distinct phases could be visually distinguished (Fig. 5b): phase (I) of generally decreasing photosynthesis, which lasted from the beginning of measurements to February; phase (II) of low photosynthesis lasting from February to April; and a recovery phase (III) from April to June.

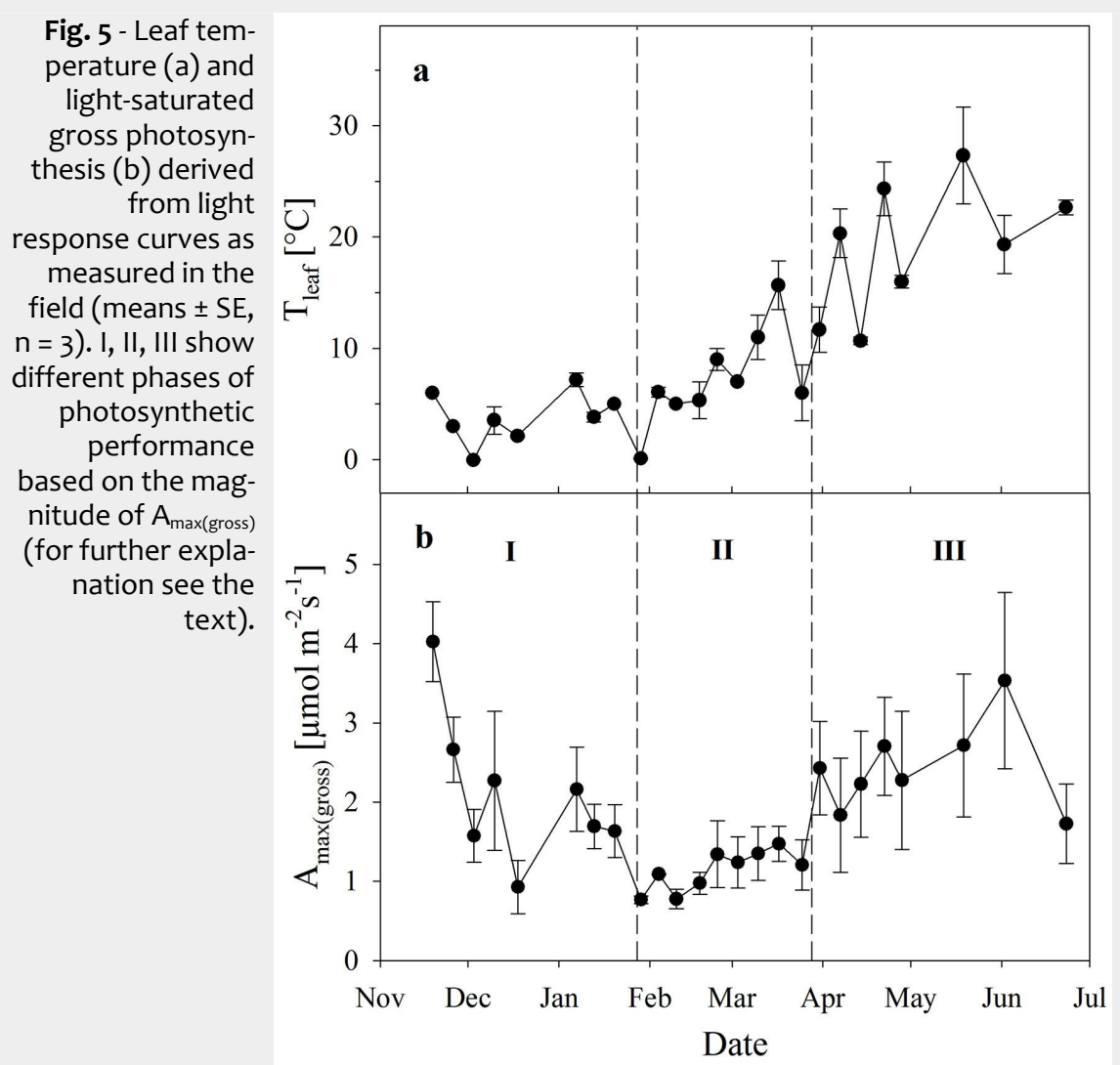

During phase I, $A_{\max (g r o s s)}$ was not only affected by $T_{\text {leaf }}$, but very likely also by the acclimation to long-lasting low air temperatures (and frosts) in combination with low radiation (Fig. 2), these being the conditions which induce frost-hardening (Huner et al. 1993, Öquist \& Huner 2003). Until about February, $A_{\max (\text { gross })}$ decreased and increased with $\mathrm{T}_{\text {leaf }}$ (Fig. 5a, Fig. 5b). Even at a $T_{\text {leaf }}$ of $0{ }^{\circ} \mathrm{C}$ (December 3 ) leaves of llex exhibited $A_{\max (\text { gross) }}$ of $1.57 \pm 0.34 \mu \mathrm{mol} \mathrm{m} \mathrm{m}^{-2} \mathrm{~s}^{-1}$ (mean $\pm \mathrm{SE}, \mathrm{n}=3$ ). Low temperatures $(5$ day mean temperatures below $4{ }^{\circ} \mathrm{C}$, in one case even $-0.5^{\circ} \mathrm{C}$ ) and likely also the continuously low radiation (Fig. $2 \mathrm{~d}$ ) could have resulted in further frost-hardening of photosynthesis, so that even lower photosynthetic rates than those observed in December resulted for the same $T_{\text {leaf }}$, e.g., now $A_{\max (\text { gross })}$ was only $0.76 \pm 0.05 \mu \mathrm{mol} \mathrm{m}^{-2} \mathrm{~s}^{-1}$ ( $\mathrm{n}$ $=3$ ) at $\mathrm{T}_{\text {leaf }}$ of $0^{\circ} \mathrm{C}$ (on January $\left.29^{\text {th }}\right)$.

During the following weeks until April (phase II), $A_{\max (\text { gross) }}$ in the field was lower for the same or higher $T_{\text {leaf }}$ compared to phase I, and remained at a relatively consistent low rate despite the increasing temperature (Fig. 5). Although $A_{\max (\text { gross }}$ already decreased during phase $I$, it is worth noting that phase II started with the longest-lasting cold period in the field (transition from January to February - Fig. 2d).

From April onwards (phase III), when temperature and radiation in the field markedly increased (Fig. 2), photosynthesis gradually recovered so that $A_{\max (\text { gross) }}$ in the field clearly increased again with rising temperatures. Although leaves reached photosynthetic rates as high as at the beginning of the experiment (Fig. 5b), this occurred at a higher $\mathrm{T}_{\text {leaf }}$ (Fig. 5a), where an even higher photosynthetic rate would have to be expected.

The apparent quantum yield of $\mathrm{CO}_{2}$ assimilation ( $\phi_{\text {i, }}$ Fig. 6b) behaved relatively similar to what was observed for $A_{\max (\text { gross })}$ in 
the field (Fig. 5 and Fig. 6a). The response of $F_{v} / F_{m}$ was also similar, showing lowest values at highest variation during phase II (Fig. 6c). Both light compensation point and light saturation of net carbon gain (not shown) increased with time from an average of about $11 \mu \mathrm{mol} \mathrm{m} \mathrm{m}^{-2} \mathrm{~s}^{-1}\left(\mathrm{I}_{\text {comp }}\right)$ and 149 $\mu \mathrm{mol} \mathrm{m} \mathrm{m}^{-2}\left(\mathrm{I}_{\text {sat }}\right)$ in phase I to $27 \mu \mathrm{mol} \mathrm{m} \mathrm{m}^{-2}$ and $158 \mu \mathrm{mol} \mathrm{m} \mathrm{m}^{-2}$ in phase II and $36 \mu \mathrm{mol}$ $\mathrm{m}^{-2} \mathrm{~s}^{-1}$ and $176 \mu \mathrm{mol} \mathrm{m} \mathrm{m}^{-2} \mathrm{~s}^{-1}$ in phase III. Based on the relatively low $I_{\text {comp }}$ during winter, it can be assumed that I. aquifolium potentially exhibited a positive net daily photosynthesis on most winter days. Moreover, even in winter, light-saturation of photosynthesis was reached almost every day. In combination with low respirational losses at low temperatures during nighttime (Fig. 3), one can assume a low but positive carbon balance on the leaf level in this species over the whole winter period.

\section{Short- and long-term recovery of photosynthesis}

In order to quantify the short-term recovery of photosynthesis from ambient winter conditions, plants were always taken into the laboratory for one night after having been measured in the field. After about 13 to $15 \mathrm{~h}$ at laboratory temperature, measurements were repeated here and compared to both their photosynthetic performance in the field and that of the reference plants. Although measurements in the laboratory were always performed under the same conditions $\left(\mathrm{T}_{\text {leaf }}=21{ }^{\circ} \mathrm{C}\right)$, all three phases of photosynthetic performance described above could be observed here (Fig. 6a-c).

Phase I: during the first weeks $A_{\max (\text { gross })}$, $\phi_{i}$ and $F_{v} / F_{m}$ of the same leaves reached significantly higher values in the laboratory (open triangles in Fig. 6a-c) than in the field (closed triangles). Over time, however, $A_{\max (\text { gross })}$ and $\phi_{\mathrm{i}}$ clearly decreased. At the end of Phase I, significant differences between measurements in the field and laboratory could only be observed for $F_{v} / F_{m}$ (Fig. 6d).

To evaluate the potential of photosynthetic parameters to recover in the longterm (Fig. 7), parameters of field plants measured in the laboratory (open triangles in Fig. 6a-c) were set into relation to that of the reference plants, taking reference values at a given date via regression curves in Fig. 6 always as 100\% irrespective of absolute changes over time: within the first two weeks from the beginning of measurements, all photosynthetic parameters were able to fully recover within one night at laboratory conditions. Afterwards, regeneration capability of $A_{\max (\text { gross })}$ and $\phi_{i}$ decreased gradually, while $F_{v} / F_{m}$ could fully regenerate over the whole of phase I (Fig. 7).

Phase II: the frost-hardening in phase I (Öquist \& Huner 2003) was very likely completed in phase II. Consequentially, all photosynthetic parameters showed lowest rates, both in the field and after short-term recovery in the laboratory (Fig. $6 \mathrm{a}-\mathrm{c}$ ). Test-

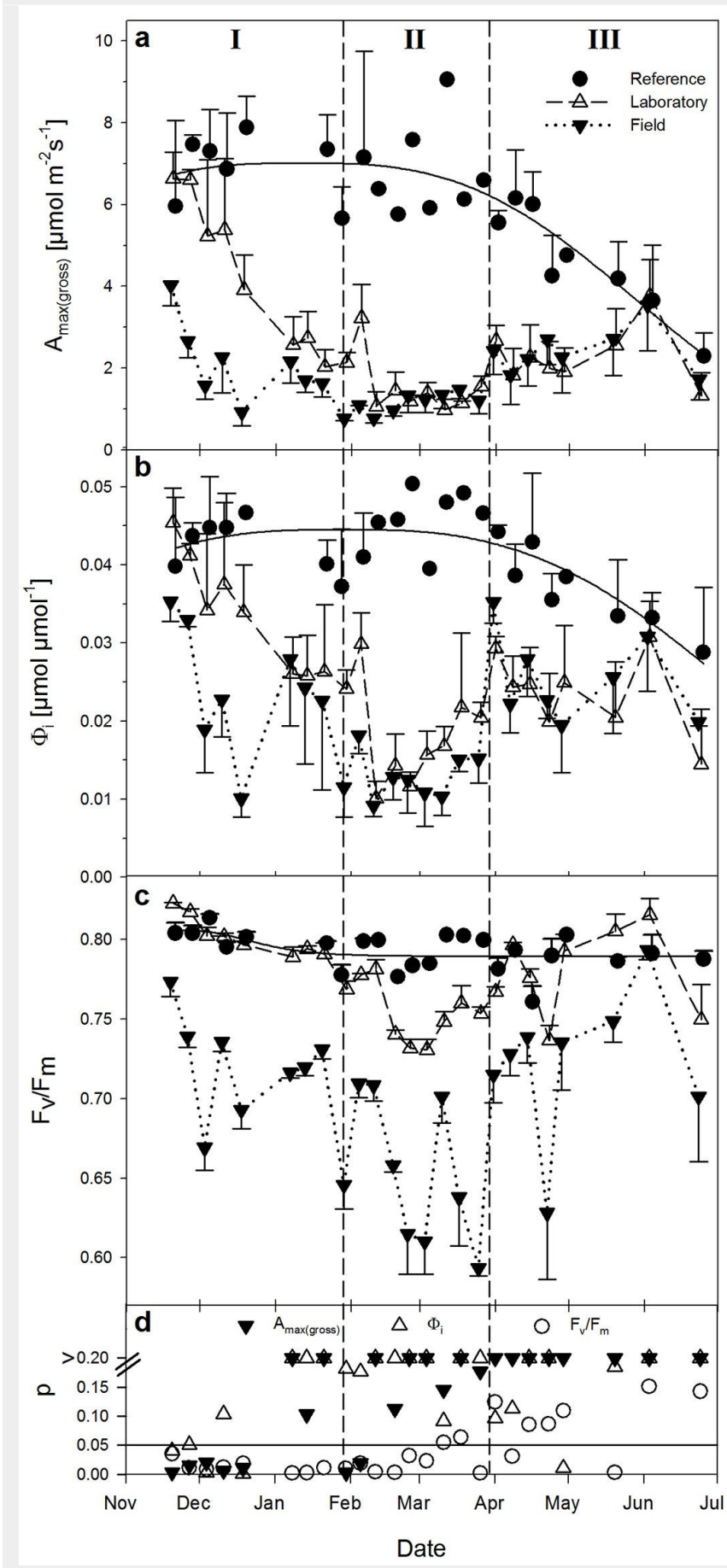

Fig. 6 - Courses of light-saturated gross photosynthesis (a), apparent quantum yield of $\mathrm{CO}_{2}$-assimilation (b) and maximal quantum yield of PSII (c) over time in leaves of reference plants (closed circles, $n=1-2$ ), in leaves of plants measured in the field (closed triangles, $n=3$ ) and the same leaves measured in the laboratory after one night of acclimatization (open triangles, $\mathrm{n}=$ 3); all means \pm SE. Graph (d) shows the level of significance ( $p$-value) derived by paired $t$-tests between leaves measured inside the laboratory and the same leaves measured in the field (as shown in a-c).

ing these variations for statistical significance (Fig. 6d), however, shows a recovery from field conditions for $A_{\max (\text { gross) }}$ at the beginning of phase II (closed triangles at $p<$ 0.05 ), but no longer thereafter. In contrast, the electron transport related $F_{v} / F_{m}$ recovered significantly during most of phase II, although not completely (open triangles in Fig. $6 \mathrm{C}$ and open circles in Fig. 7). This physiological state lasted for almost two months.

At this point one might question the artificial determination of phases. Based on $A_{\max (\text { gross })}$ one could argue for the beginning of phase II after the last observed recovery in February, whereas our decision was based on the absolute amount of $A_{\max (g r o s s)}$ remaining low from the end of January onwards (Fig. 5b). Nevertheless, results obtained and conclusions drawn would not be affected.

Phase III: with the beginning of spring at the end of March, photosynthesis increased again both in the field and in the laboratory (Fig. 6a-c), thus showing no significant differences between field and short-term recovery over most of the time (Fig. 6d). With time, all parameters gradually recovered from winter conditions (Fig. 7). This long-term recovery of photosynthesis in spring is very likely a consequence of increasing ambient temperature and radiation (Fig. 2a, Fig. 2b, Fig. 2d). 


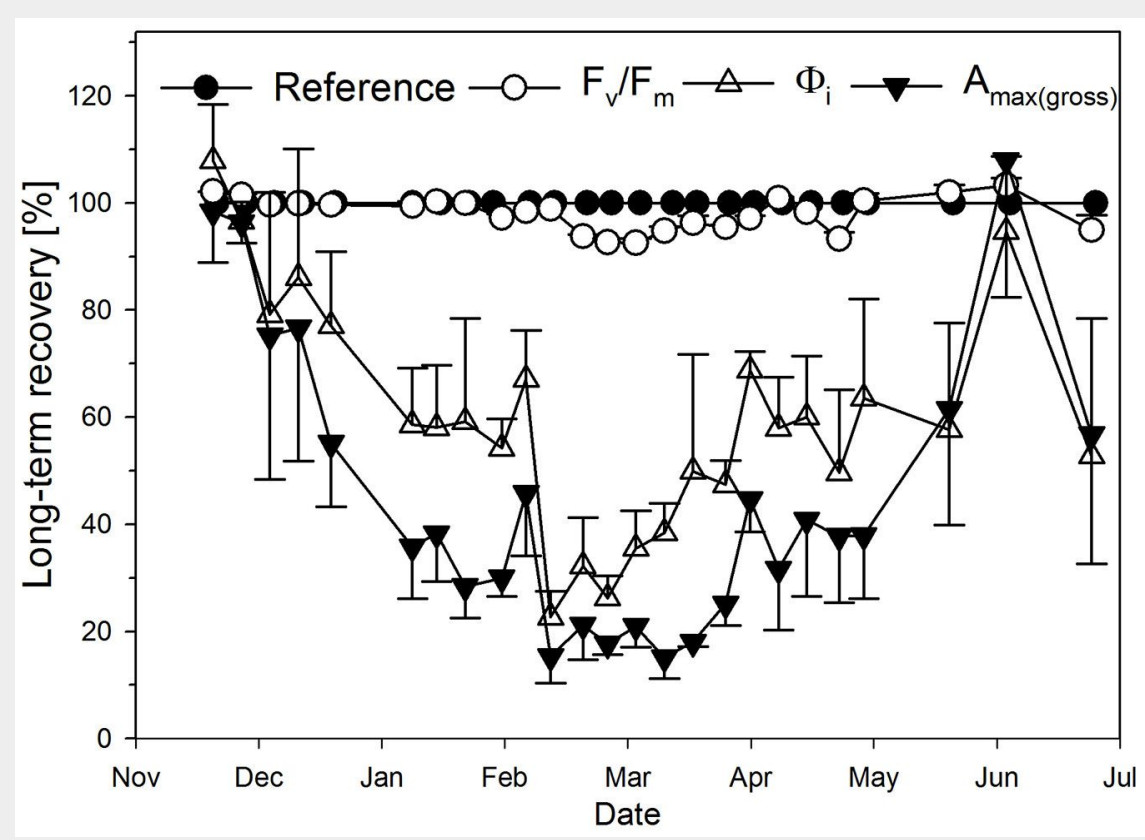

Fig. 7 - Changes in recovery of photosynthetic parameters in the long-term: photosynthetic parameters of field plants which were measured after one night of acclimatization in the laboratory (see open triangles in Fig. $6 \mathrm{a}-\mathrm{c}$ ), in relation to the same parameters of reference plants (always taken here as $100 \%$ via the respective regression curves of Fig. 6a-c).

\section{Discussion}

\section{Photosynthesis in winter}

There are two completely different major traits in plants concerning mechanisms for adjusting photosynthesis to winter conditions, probably as a consequence of different leaf longevities. While herbaceous winter annuals (e.g., winter wheat) adjust their photosynthesis to maximize carbon gain during winter, they retain a higher photosynthetic activity at the risk of (total) leaf damage by frost. In contrast, conifers pro- tect their much longer-lived leaves from frost damage by inducing frost resistance and photoprotection at the cost of drastically decreased carbon gains (Bauer et al. 1994, Savitch et al. 2002, Ensminger et al. 2006). This reduction of photosynthesis during winter is reported in many studies and is therefore quite well-known (Havranek \& Tranquillini 1995). The vast majority of this research, however, has been conducted on conifers, but only rarely on evergreen broadleaved trees. Our results show that down regulation of photosynthesis

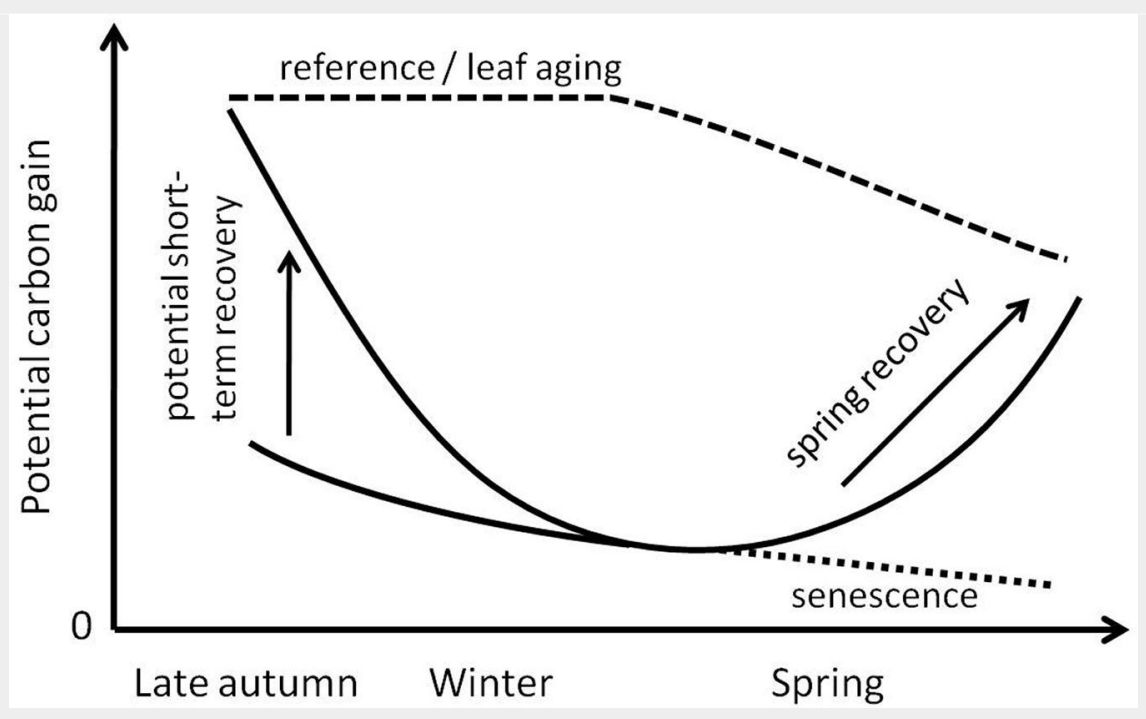

Fig. 8 - Simplified scheme of potential carbon gain $\left(A_{\max (\text { gross) }}, \phi_{i}\right)$ of I. aquifolium over the time when deciduous trees are leafless, and the capability of the photosynthetic apparatus to recover from low temperatures during a warm day in autumn and winter (short-term recovery), as based on the observations presented in Fig. 6 and Fig. 7. during winter in I. aquifolium follows the same "strategy" as mentioned above for conifers.

We observed decreasing light-saturated photosynthetic rates in the field from November to February which could not be explained by decreasing temperatures alone (Fig. 5). Also, the ability of photosynthetic parameters $\left(A_{\max (\text { gross })}\right.$ and $\left.\phi_{i}\right)$ to recover overnight under laboratory conditions declined with time (Fig. 6a, Fig. 6b). This behavior likely resulted from a gradually developing freezing tolerance (frost-hardening) in leaves, as has been shown by Bauer et al. (1994) for different conifers, and which is induced by long-lasting low temperatures in combination with reduced radiation and a shorter photoperiod (Huner et al. 1993, Öquist \& Huner 2003). The assumed process of frost-hardening lasted for more than two months and was completed after the longest-lasting cold period in the field at the beginning of February. As a result of the frost-hardening (and probably of chronic photoinhibition, see below), the following phase (February and March) was characterized by continuously low rates of photosynthetic carbon gain and the lowest ability of all photosynthetic parameters to recover from winter conditions. Nevertheless, even during this time, I. aquifolium exhibited a low but positive net photosynthesis at a $\mathrm{T}_{\text {leaf }}$ of around zero with sufficient light.

In Central Europe, I. aquifolium is naturally growing in the understory of deciduous beech forests at reduced light availability during the vegetation period. In this situation, even a low carbon gain over winter (below the now leafless canopies) might be important for the annual carbon gain. For example, Katahata et al. (2014) reported that carbon gain in the evergreen Daphniphyllum humile (an understory shrub growing in cool-temperate deciduous forests in Japan) during the leafless period in autumn accounted for approximately $49 \%$ of its annual carbon gain. This might be similar in I. aquifolium, since leaves measured here showed relatively high potential carbon assimilation until the end of January (Fig. 5b). However, the gradually increasing inability to regenerate photosynthesis overnight in the laboratory leads to the assumption that I. aquifolium can only slightly profit (in terms of carbon gain) from single warmer days in winter once the frost-hardening is initiated, and it cannot profit at all once frost-hardening is completed. It is even possible that net carbon gain slightly decreases due to increased respiration during warm periods (Busch et al. 2007). Similar results have been recently shown by Bowling et al. (2018) by use of the eddy covariance method in a subalpine conifer forest in the Rocky Mountains of Colorado, where an increase of photosynthetic carbon gain during favorable days in winter could not be detected when trees were in dormancy.

These findings seem contradictory to 
chlorophyll fluorescence measurements, which indicate a much better potential for photosynthesis on warm days in winter. From experiments by Groom et al. (1991) and Veste \& Kriebitzsch (2010) we know that $F_{v} / F_{m}$ in $I$. aquifolium can recover within hours when cold acclimated leaves were transferred to more favorable conditions, thus indicating a high plasticity of the light absorbing part of the photosynthetic apparatus. These results are in agreement with our observations. The above-mentioned authors, however, did not measure leaf gas exchange. From our results we cannot confirm this fast and almost complete recovery overnight for the actual photosynthetic carbon assimilation rate. A longer acclimation time, however, might alter this result. Acclimation at favorable conditions $\left(18{ }^{\circ} \mathrm{C}\right)$ lasting about 3.5 times longer than in our experiment $(48 \mathrm{~h})$ increased light saturated rates and apparent quantum yield of photosynthetic $\mathrm{O}_{2}$-evolution in Pinus sylvestris to fully recover from outside winter conditions (Ottander \& Öquist 1991). In support of this, Wieser (1997) showed that $\mathrm{CO}_{2}$ gas exchange in Pinus cembra at an alpine timberline was almost completely suppressed during winter and net photosynthesis increased up to $30 \%$ of summer values during an extended warm period.

\section{Photoinhibition}

Under high light conditions, especially in winter when temperatures are low, photosynthesis of I. aquifolium (and other plants) may suffer from photoinhibition, as indicated by a reduction in $F_{v} / F_{m}$ (Groom et al. 1991, Valladares et al. 2005). Veste \& Kriebitzsch (2010) have shown that the potential PSII efficiency $\left(F_{v} / F_{m}\right)$ in I. aquifolium shows a high plasticity during winter and that $\mathrm{F}_{\mathrm{v}} / \mathrm{F}_{\mathrm{m}}$ could fully recover within two hours when plants were transferred from temperatures close to $0{ }^{\circ} \mathrm{C}$ (field) to $20{ }^{\circ} \mathrm{C}$ (greenhouse). According to these studies, the llex leaves in our study experienced photoinhibition over most of the experimental period when in the field. During phases I and III, $F_{v} / F_{m}$ could, however, fully recover overnight after plants were transferred into the laboratory (Fig. 6c), which indicates that certain sections of the photosynthetic apparatus were not suffering longer lasting "stress" over these periods. If $\mathrm{F}_{\mathrm{v}} / \mathrm{F}_{\mathrm{m}}$ in darkened leaves does not recover after $2 \mathrm{~h}$ of acclimation at favorable conditions, then photoinhibition can be seen as chronic (Míguez et al. 2015). This was the case here during phase II (February and March), when even after over $12 \mathrm{~h}$ at laboratory conditions, $F_{v} / F_{m}$ could not fully recover so that a longer lasting PSII depression can be assumed, which is also supported by decreased $\phi_{\mathrm{i}}$ (Fig. 6b, Fig. 6c).

\section{Spring recovery and leaf aging}

For boreal coniferous forests, Suni et al. (2003) showed that the beginning of spring-recovery of photosynthesis correlates best with a 5-day average of ambient temperatures (between $3.3^{\circ} \mathrm{C}$ and $6.5^{\circ} \mathrm{C}$ ). In our study, spring-recovery of $A_{\max (\text { gross })}$ was most likely initiated at the end of phase II in mid-March when the 5-day average temperature was above $5{ }^{\circ} \mathrm{C}$ and radiation clearly increased (Fig. 2d, Fig. 7). Nevertheless, such threshold values remain questionable. Independent of this, the recovery of $F_{v} / F_{m}$ and $\phi_{i}$ began about 1-2 weeks earlier than that of $A_{\max (\text { gross) }}$ (Fig. 7), making a reduction of photoinhibitory stress likely (see above).

Although $A_{\max (\text { gross })}$ clearly rose again with the beginning of spring, leaves exhibited lower photosynthetic rates as compared to the previous autumn. A reason for these lower rates might be that photosynthesis has not yet fully recovered from winter, or leaves measured here during early and late spring could have come close to the end of their life spans. On average, leaves of $I$. aquifolium have a longevity of two years, and their photosynthetic rates gradually decrease with age (Mediavilla \& Escudero 2003). A gradual decrease of photosynthetic rates over time was also observed in leaves of both reference plants in the laboratory (Fig. 6a) despite continuously favorable conditions.

\section{Conclusion}

Similar to evergreen conifers, evergreen I. aquifolium down-regulates photosynthesis during winter. During the process of frost hardening, photosynthesis gradually loses its ability to recover under more favorable conditions (this is schematically summarized in Fig. 8). One night of warm temperatures is not sufficient to induce recovery during the hardened phase, where rates of photosynthetic carbon gain stay at about $15 \%$ to $20 \%$ of those in the pre-hardened phase. Chlorophyll fluorescence measurements indicate a much better recovery potential and implicate higher rates of photosynthetic carbon gain than could be observed, and can, therefore, not reliably predict carbon gain during winter. Obviously the light absorbing part of photosynthesis enabling the early electron transport chain $\left(F_{v} / F_{m}\right)$ behaves differently from the following biochemistry, especially in the Calvincycle $\left(A_{\max }\right)$. If not in the complete steadystate, they may behave uncoupled. With regards to carbon gain, I. aquifolium in Central Europe might not profit significantly from single warmer days in winter unless the pre-hardening phase gets extended (e.g., by global warming) or the frost-hardened phase becomes shortened.

\section{Acknowledgements}

We thank Margaret Eppli (Hohenheim, Stuttgart, Germany) for proofreading the manuscript and correcting the English.

\section{References}

Arrieta S, Suárez F (2006). Marginal holly (Ilex aquifolium L.) populations in Mediterranean central Spain are constrained by a low-seedling recruitment. Flora 201: 152-160. - doi: 10.1016/j. flora.2005.05.002

Banuelos MJ, Kollmann J, Hartvig P, Quevedo M (2004). Modelling the distribution of llex aquifolium at the north-eastern edge of its geographical range. Nordic Journal of Botany 23: 129-142. - doi: 10.1111/j.1756-1051.2003.tboo374.x Bauer H, Nagele M, Comploj M, Galler V, Mair M, Unterpertinger $E$ (1994). Photosynthesis in cold acclimated leaves of plants with various degrees of freezing tolerance. Physiologia Plantarum 91: 403-412. - doi: 10.1111/j.1399-3054.19 94.tbo2967.x

Berger S (2008). Evergreen broad-leaved woody species: indicators of climate change. PhD thesis, Naturwissenschaftliche Fakultät, Gottfried Wilhelm Leibniz Universität Hannover, Hannover, Germany, pp. 121.

Bowling DR, Logan BA, Hufkens K, Aubrecht DM, Richardson AD, Burns SP, Anderegg WRL, Blanken PD, Eiriksson DP (2018). Limitations to winter and spring photosynthesis of a Rocky Mountain subalpine forest. Agricultural and Forest Meteorology 252: 241-255. - doi: 10.1016/ j.agrformet.2018.01.025

Busch F, Hüner NPA, Ensminger I (2007). Increased air temperature during simulated autumn conditions does not increase photosynthetic carbon gain but affects the dissipation of excess energy in seedlings of the evergreen conifer Jack pine. Plant Physiology 143: 12421251. - doi: 10.1104/pp.106.092312

Bussotti F, Pollastrini M, Holland V, Brüggemann W (2015). Functional traits and adaptive capacity of European forests to climate change. Environmental and Experimental Botany 111: 91-113. - doi: 10.1016/j.envexpbot.2014.11.006

Chazdon RL, Pearcy RW (1986). Photosynthetic responses to light variation in rainforest species. I. Induction under constant and fluctuating light conditions. Oecologia 69: 517-523. doi: $10.1007 /$ BFo0410357

DWD (2014). Deutschlandwetter im Winter 2013/14 [Germany's weather in the 2013/14 winter]. Deutscher Wetterdienst, Pressemitteilung, Offenbach, Germany. [in German] [online] URL: http://www.dwd.de/DE/presse/pressemitteilun gen/DE/2014/20140227_DeutschlandwetterimW inter.pdf?_blob=publicationFile \&v $=6$ Ensminger I, Busch F, Huner NPA (2006). Photostasis and cold acclimation: sensing low temperature through photosynthesis. Physiologia Plantarum 126: 28-44. - doi: 10.1111/j.1399-3054. 2006.00627.x

García-Plazaola Jl, Olano JM, Hernandez A, Becerril JM (2003). Photoprotection in evergreen Mediterranean plants during sudden periods of intense cold weather. Trees 17: 285-291. [online] URL: http://link.springer.com/article/10.1007/so 0468-002-0234-y

Gillies SL, Vidaver W (1990). Resistance to photodamage in evergreen conifers. Physiologia Plantarum 80: 148-153. - doi: 10.1111/j.1399-3054. 1990.tbo4389.x

Groom QJ, Baker NR, Long SP (1991). Photoinhibition of holly (Ilex aquifolium) in the field during the winter. Physiologia Plantarum 83: 585590. - doi: 10.1111/j.1399-3054.1991.tbo2472.x

Havranek WM, Tranquillini W (1995). Physiological processes during winter dormancy and their ecological significance. In: "Ecophysiology of Coniferous Forests” (Smith WK, Hinckley TM 
eds). Academic Press, San Diego, USA, pp. 95124. - doi: 10.1016/B978-0-08-092593-6.50010-4 Huner NPA, Öquist G, Hurry VM, Krol M, Falk S, Griffith M (1993). Photosynthesis, photoinhibition and low temperature acclimation in cold tolerant plants. Photosynthesis Research 37: 19-39. - doi: 10.1007/BF02185436

Iversen J (1944). Viscum, Hedera and Ilex as climate indicators. Geologiska Föreningen i Stockholm Förhandlingar 66: 463-483. - doi: 10.1080/ 11035894409445689

Kaiser E, Morales A, Harbinson J, Kromdijk J, Heuvelink E, Marcelis LFM (2015). Dynamic photosynthesis in different environmental conditions. Journal of Experimental Botany 66: 24152426. - doi: $10.1093 / j \times b / e r u 406$

Katahata SI, Han Q, Naramoto M, Kakubari Y, Mukai $Y$ (2014). Seasonal changes in temperature response of photosynthesis and its contribution to annual carbon gain in Daphniphyllum humile, an evergreen understorey shrub. Plant Biology 16: 345-353. - doi: 10.1111/plb.12046 Mediavilla S, Escudero A (2003). Photosynthetic capacity, integrated over the lifetime of a leaf, is predicted to be independent of leaf longevity in some tree species. New Phytologist 159: 203211. - doi: 10.1046/j.1469-8137.2003.00798.x

Míguez F, Fernández-Marín B, Becerril JM, García-Plazaola Jl (2015). Activation of photoprotective winter photoinhibition in plants from different environments: a literature compilation and meta-analysis. Physiologia Plantarum 155: 414-423. - doi: 10.1111/ppl.12329

Öquist G (1983). Effects of low temperature on photosynthesis. Plant, Cell and Environment 6:
281-300. - doi: 10.1111/1365-3040.ep11612087 Öquist G, Huner NPA (2003). Photosynthesis of overwintering evergreen plants. Annual Review of Plant Biology 54: 329-355. - doi: 10.1146/ annurev.arplant.54.072402.115741

Ottander C, Öquist G (1991). Recovery of photosynthesis in winter-stressed Scots pine. Plant, Cell and Environment 14: 345-349. - doi: 10.1111/j. 1365-3040.1991.tb01511.x

Pott R (1990). Die nacheiszeitliche Ausbreitung und heutige pflanzensoziologische Stellung von Ilex aquifolium L. [Post-glacial distribution and current phyto-sociological role of llex aquifolium L.]. Tuexenia 10: 497-512. [in German]

Savitch LV, Leonardos ED, Krol M, Jansson S, Grodzinski B, Huner NPA, Öquist G (2002). Two different strategies for light utilization in photosynthesis in relation to growth and cold acclimation. Plant, Cell and Environment 25: 761-771. - doi: 10.1046/j.1365-3040.2002.00861.x

Slot M, Wirth C, Schumacher J, Mohren GMJ, Shibistova O, Lloyd J, Ensminger I (2005). Regeneration patterns in boreal Scots pine glades linked to cold-induced photoinhibition. Tree Physiology 25: 1139-1150. - doi: 10.1093/treephys/ 25.9.1139

Suni T, Berninger F, Vesala T, Markkanen T, Hari $P$, Mäkelä $A$, Ilvesniemi $H$, Hänninen $H$, Nikinmaa E, Huttula T, Laurila T, Aurela M, Grelle A, Lindroth A, Arneth A, Shibistova O, Lloyd J (2003). Air temperature triggers the recovery of evergreen boreal forest photosynthesis in spring. Global Change Biology 9: 1410-1426. doi: 10.1046/j.1365-2486.2003.00597.x

Sykes MT, Prentice IC, Cramer W (1996). A biocli- matic model for the potential distributions of North European tree species under present and future climates. Journal of Biogeography 23: 203-233. [online] URL: http://www.jstor.org/sta ble $/ 2845812$

Valladares F, Arrieta S, Aranda I, Lorenzo D, Sánches-Gómez D, Tena D, Suárez F, Pardos JA (2005). Shade tolerance, photoinhnibition sensitivity and phenotypic plasticity of Ilex aquifolium in continental-Mediterranean sites. Tree Physiology 25: 1041-1052. - doi: 10.1093/tree phys/25.8.1041

Veste M, Kriebitzsch WU (2010). Die Stechpalme - ein Gewinner des Klimawandels? [Holly - a winner of global warming?]. AFZ-DerWald 16: 16-18. [in German]

Wachendorf M, Küppers M (2017). Effects of leaf temperature on initial stomatal opening and their roles in overall and biochemical photosynthetic induction. Trees 31: 1667-1681. - doi: 10.1007/s00468-017-1577-8

Walther G, Berger S, Sykes MT (2005). An ecological "footprint" of climate change. Proceedings of The Royal Society B 272: 1427-1432. - doi: 10.1098/rspb.2005.3119

Way DA, Pearcy RW (2012). Sunflecks in trees and forests: from photosynthetic physiology to global change biology. Tree Physiology 32: 1066-1081. - doi: 10.1093/treephys/tpso64

Wieser $G$ (1997). Carbon dioxide gas exchange of cembran pine (Pinus cembra) at the alpine timberline during winter. Tree Physiology 17: 473477. - doi: 10.1093/treephys/17.7.473 